\title{
FROM VERBAL PREFIXES TO DIRECTION/RESULT MARKERS IN ROMANCE
}

\section{VERB - LOCATIVE CONSTRUCTIONS IN ROMANCE ${ }^{1}$}

It is well known that standard Romance languages, following the classical Latin tradition, employ prefixes - more or less opaque - and make a restricted use of verblocative (or verb-particle) constructions, in order to express spatial information with verbs. ${ }^{2}$ Italian, French, Spanish, Romanian, Catalan and Portuguese grammars and dictionaries register prefixed verbs, and only marginally the corresponding analytic constructions, with a verb followed by a locative, forming one lexical element. ${ }^{3}$ Differently, analytic constructions (called in English "phrasal verbs", in German "trennbare Verben") are very common in Germanic languages. ${ }^{4}$

However, the evolution of the Latin syntactical type SOV into the present SVO type - which was fundamental to the weakening of the case system and has led to the formation of prepositions to express syntactical relations - has affected the prefix system too, making it less transparent and less productive. ${ }^{5}$ Thus, when we look to diatopic ${ }^{6}$, diachronic ${ }^{7}$, diaphasic and diastratic ${ }^{8}$ varieties of Romance, we note that they frequently substitute prefixed verbs with verbs plus locative constructions. This phenomenon has been discussed mainly on Italian data, since in colloquial Italian it is largely attested and various kinds of verbs followed by locatives are employed ${ }^{9}$.

\footnotetext{
* Author's address: Facoltà di Lettere e Filosofia, Dipartimento di Studi Letterari Linguistici e Filologici, Via S.Croce, 65, Trento, Italia. Email: patrizia.cordin@unitn.it

${ }^{1}$ I use the term 'locative' both for referring to places and to directions.

${ }^{2}$ Verb-locative constructions are attested in non classical Latin texts; see Durante (1981) and Vincent (1999).

${ }^{3}$ On standard Italian, Spanish and Catalan grammars and dictionaries see Calvo (2010).

${ }^{4} \mathrm{~A}$ recent overview on the construction in Germanic languages is presented in Dehé et alii (2002).

5 On the decline of the Latin system of verbal prefixation and the progressive loss of transparency and productivity see Iacobini (2004) and Masini (2006: 81-84).

${ }^{6}$ On northern Italian dialects and Ladin see Rohlfs (1969), Gsell (1982), Spiess (1983); more recently the construction in northern Italian varieties has been discussed by Vicario (1997), Benincà/Poletto (2006), Vigolo (2007), Cini (2008), Cordin (2011). Acadian French verbal constructions with locatives are given in King (2000).

${ }^{7}$ Old French examples are discussed in Dufresne et alii (2003); for ancient Italian see Masini (2006) and Jezek/Strik-Lievers (2010); for old Italian dialects see Cordin (2011).

8 See Iacobini/Masini (2007).

${ }^{9}$ Among others, see Schwarze (1985), Simone (1997), Jansen (2004), Cini (2008).
} 
In fact, in spoken Italian we find:

a) stative verbs + locative: stare su = raddrizzarsi 'to stand up', stare via = assentarsi 'to be away';

b) intransitive motion verbs + locative: 10 andar fuori = uscire 'to go out', andar su = salire 'to go up', correr dietro = rincorrere 'to chase', venir dentro = entrare 'to come in';

c) transitive motion verbs + locative: buttar via $=$ eliminare 'to throw away', metter dentro $=$ inserire 'to put into', tirar su = raccogliere 'to pick up';

d) figurative motion verbs + locative: tirarsi su = diventare allegri 'to get better', metter sotto = soggiogare 'to keep somebody down' or investire 'to knock somebody down'; tirar avan$t i=$ sopravvivere 'to survive', andar fuori = ammattire 'to be out of ones's mind';

e) activity verbs + locative: grattar via $=$ raschiare 'to scrape away', lavar via = ripulire 'to wash away', strappar via 'to rip off', cancellar via = scancellare 'to delete'.

The verbs in e), which in Romance area seem peculiar to Italian, deserve a particular attention: the locative via 'away' is used in combination with verbs of manner that contain a semantic feature of removing. The adverb expresses not only the direction that is involved as a component of the activity, but - as Iacobini/Masini (2007) notice- it gives an aspectual information, suggesting a telic reading, that emphasizes the success of the process and that underlines its result, changing an activity into an accomplishment.

The aspectual function of the adverb in verb-locative constructions is more evident in some northern Italian dialects, where - as we will see in next paragraph - it is not limited to verbs that semantically encode a feature of removing and is not restricted to the adverb via 'away'.

\section{FROM SPACE TO ASPECT}

The verb-locative construction is largely attested in some dialects of northern Italy (in particular Friulan, Veneto, Piedmontese, Lombard, Trentino), where locative adverbs appear not only in combination with motion verbs (excluded manner motion verbs), but also with different kinds of transitive verbs and unaccusative verbs, where locatives contribute to give some aspectual interpretations of the event. In these dialects locatives combine frequently with transitive verbs where an action is performed on an affected object: their interpretation is still connected (although indirectly) to directionality, in that they specify the end-point of a movement that characterizes the action, usually carried out with the hands or arms, as already noticed for Italian verbs like raschiare via. In dialectal varieties, however, the 'resultativization' through the combination of a verb and a locative is much more frequent, as the following examples taken from Trentino illustrate. ${ }^{11}$ I group them under e'):

\footnotetext{
${ }^{10}$ Manner motion verbs, however, cannot co-occur with a locative, as it will be illustrated in footnote 22 .

11 More examples - taken from ALTR (2005) and Grassi (2009)- are discussed in Cordin (2011).
} 
e') coertàr su to cover with a blanket; to cover something, eg wood, with a canvas etc., to shelter it, copiar oo to copy out, desfàr giu to wind up, destèndar fò to unfold, to spread out, destrigàr fora or destrigàr via to tidy up, put things away, make space, far su to build, to put up, to raise, far $\delta o$ to slice (potatoes, apples), fregàr su to polish the floor, inciavar via to lock away, lavàr fò to wash out a large container, lavàr giu to do the washing up, lavàr su to clean the floor, misiàr su to stir, netàr fò to do the clearing, rasàr via to rub (away), rebaltàr su to turn, to knock over, refàr su to rebuild, regolàr via to tidy (away), schiciàr, scuciàr o strucàr fò to squeeze something hard to get the liquid that it contains out, to squeeze, scónder via to cover up a thing, so that it can't be seen, scrivar giu to write down, śgrafàr $\delta o$ to scrape off, spazàr su to sweep, spazàr $\delta o$ to brush down an item of clothing, sugàr giu i pı̌ac, le pośade, i bicér to dry up (after the washing up), sugàr su to dry a wet table or floor, taĭàr giu to cut, to chop off; to slice, to cut in slices, zoncàr via to cut, to chop off

The telic interpretation is more evident in those constructions where locatives (mainly su 'up' and fora 'out', 'off') combine with unaccusative verbs or with other transitive verbs that do not express actionality carried out phisically with hands and directed to a specific endpoint, as in e). The telic constructions given in f) often require as direct object a plural noun, or a singular collective noun, or a quantified noun (particularly the pronoun tutto, tutti 'all', or the adjective tutto + noun):

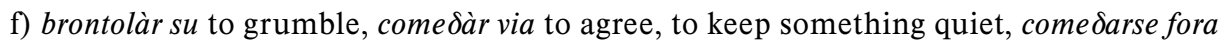
to work out, to come out right (of a situation), contàr fora tut to blurt up, to blab, to gossip, contàr su to tell, contentar via to keep happy, to please, dir fora to blab, dir su to talk big, to tell stories, to spin a good yarn, emblogiarse su, engranizarse su to dirty, to soil, to smear oneself, eg with soot, finir fò to get through (everything), to use up, fracasàr su tut to break everything, imbotonarse su to button up (one's cloths), magnàr fò to polish off (a meal, food), morì fora to die (back, off), morìr $\delta o$ (of fire) to go down, to die down, pagàr fora to liquidate, to pay off, to sell out, scaldar fora to heat, studiar fora to examine, spozzarse su to become black, to darken, to get filthy, squèrzirse su polito to wrap up well, to dress warmly, stropàr su tut to shut up a house before leaving it, vénder fora tut to sell out, vestirse su polito to wrap up well.

The frequency with which the quantifier tutto appears bears out the hypothesis that telicity can be linked with the idea of measuring an event, and with a scale or path which provides a means to determine the progress of an event.

Another aspectual meaning - closely connected to the measurement of an eventis expressed by the adverb $s u$ in conjunction with an action verb. The adverb suggests a certain speed in the execution of an action, leading to a loss of accuracy and a consequently unsatisfactory result. Therefore the expressed aspect is always telic, linked to a measurement of the event, with the goal of an action only partially achieved, as shown below: 
g) co me cóntet su? 'What are you saying? (I find it hard to believe that)', far su 'to be up to no good', farse su 'to dress in bad taste', giustàr su 'to patch up', rangiàr su a la mèio 'to adjust the least worst', slambrotàr su 'to speak unclearly', todescàr su 'to speak German to someone who doesn't understand'

The adverbs su and fora can also indicate the repetition of an action, or its duration. In both cases there is a measurement of the event, as illustrated by the constructions basarse su 'to kiss repeatedly', struforlarse su 'to be all over each other', brazarse su 'to embrace each other', in which the verbs describe physical contact. Also constructions with verbs related to speech, thought, sight, eg pensarghe su 'to reflect, to think about', dir su la corona 'to say the rosary', contar su na storia 'to tell a story', vardàr fò i so mistér 'to mind one's own business' indicate intensity or meticulousness.

In a small (but frequently used) group of Trentino constructions the locative adverb expresses the progress of an event rather than its result: ingressive and progressive readings in particular are attested. A locative expresses an ingressive aspect when it indicates the beginning of an action; via 'away', su 'up', 'on', often accompany and reinforce verbs which themselves express the idea of beginning: ciapàr su 'to be on the point of, to be about to', inviàr via 'to start up, to begin', mòver via 'to start something off, to open (a restaurant, etc.)', scomenzàr via 'to start off', stradàr via 'to start off'. The progressive aspect is expressed by locatives which indicate that an action is in progress, and is rendered solely by the adverb dietro 'behind' in combination with the verb esser 'to be' $+a$ + infinitive, or esser + che 'that' + finite verb: 'to be busy doing something':

h) co sét dré a far? 'what are you doing?'; lé dré che l cubia 'he's sleeping'; ié dré che i và 'they're leaving'; ié dré che i và en malga 'they're going up to the summer pastures'; l'é dré che la śbercis 'she's dying'; la vaca l'é dré a far 'the cow is about to calve'; le róse l'é dré che le śbòcia 'the roses are blooming'; lé dré ala lègna (lit. he is behind) 'he is working a) to collect wood b) to stack wood; lò gatà che léra dré a caminàr 'I found him while he was leaving'

The variety of Trentino examples given from e') to $h$ ) shows that this dialect along with others of northern Italy- has fully developed the possibilities of interpretation for the locative in the construction verb-locative, attesting a systematic passage from prefixed verbs to verbs plus locative, both with directional and with aspectual interpretation.

This tendency - although present in all Romance languages that have no rigid codification - might have been strengthened by the requirement of northern Italian dialects for spelling out inflection markers. In particular, Trentino seems to require 
also the spelling out of a goal/result marker that functions both for arguments of motion verbs and for aspect.

We know that in Italian an argument can be left unexpressed, if the context (discursive or situational) allows it to be understood. Verbs of motion often contain an unexpressed argument, usually relating to either the endpoint or the origin of their path:
1a
Entra pure (qui, in questa stanza)!
Come in (here, into this room)!
$1 \mathrm{~b}$
Quando esco (di qui, da questa casa), chiudo sempre la porta.
$1 \mathrm{c}$
When I go out (of here, of this house), I always shut the door.
È partito (dalla città) alle due in punto.
He went away (from the city) at two o'clock.

We can hypothesize that, unlike in Italian, in Trentino dialects the position of the arguments of verbs of motion must always be marked by an explicit element (which is spelled out), a locative, in fact - even in cases in which the argument noun phrase is not expressed. The spelled out element acts to mark the position of a verb of motion's internal argument. The Italian examples given in 1a-c are in fact correct in Trentino dialect, with a locative which signals the presence of the argument internal to the verbal phrase (goal, or origin), as shown in 2a-c:

$\begin{array}{ll}\text { 2a } & \text { Vèi dentro, dai! } \\ & \text { Come in! } \\ \text { 2b } & \text { Quando che vago fora, sero sempre la porta } \\ & \text { When I go out, I always shut the door. } \\ \text { 2c } & \text { L'è nà via ale doi precise. }\end{array}$

He went away at two o'clock.

Some evidence of the requirement for marking the position of a direction argument in Trentino is given by those examples in which the locative combines with a non prefixed verb whose meaning is characterized by an inherent feature of natural directionality, as cascar zo 'to fall down', levarse su 'to stand up', scampar via 'to run away', sentarse zo 'to sit down', montar su 'to go up': it is clear that the locative is required not to express directionality, which is already inherent to the verb, but rather to mark the position of the argument of the motion verb.

Further confirmation of the "argument marker" hypothesis comes from the cases in which the locative governs an unexpressed noun, whose understanding, although not provided contextually, is still made possible thanks to the verbal semantic features: méter su 'to put on (something on the fire, to cook)', tor for ua 'to take grapes, choosing them from the vineyard', tor fora (i cavai) 'to unhitch (horses from a cart etc.)', tor fora (i soldi) 'to withdraw (money)', deśniàr fò 'to flush, 
drive out an animal'. Here, too, the locative acts as the marker of an argument position (goal or origin), whose content is left implicit. ${ }^{12}$

Trentino dialects seem to require a marker not only as a signal an argument of motion verbs, but also as a marker of a dynamic feature of an event, as it happens in particular with telic verbs ${ }^{13}$. To place these observations in a wider context, I note that the requirement of an explicit marker for directional arguments and for verbal aspect can be seen as a particular instance of a rule requiring that specifiers of functional verbal categories (agreement, aspect, argument structure, modality) are spelled out. Frequently the spelling out of these elements originates doubling. As a consequence, in northern Italian dialects also the verb-locative combination can be dealt with coherently within the framework of doubling, which is relevant in these diatopic varieties, as illustrated by the Trentino examples 3-7:

Subject agreement doubling 14

3 el Mario el zuga

the Mario $3^{\text {rd }}$ p.sing. plays

Mario plays

Dative clitic doubling 15

4 ghe dago la torta ai popi

I dat.clit. $3^{\text {rd }}$ p.pl. give the cake to the kids

12 Yet another confirmation of the locative as argument-marker comes in Tortora's 2002 study of the Borgomanero dialect in Piedmont. In this dialect the locative behaves differently in sentences with object clitics in which it functions as an argument of a transitive verb of movement, and in sentences in which, on the other hand, it functions as the circumstantial complement of a transitive verb. When it is an argument, the locative occupies the position immediately to the right of the verb, before the object clitic; when it is an adjunct it occupies the position immediately to the right of the object clitic. The following examples with the locative denti/denta (inside), taken from Tortora (2002: 726) illustrate the above distinction:

$\mathrm{i}^{*}$ i porta-la denti

ii i porti denta-la

I'm bringing it inside

iii i moengia-la denti

iv*i moengia denta - la

I'm eating it inside

Note that Borgomanerese shows general clitic enclisis with both finite and infinite verbs.

13 Tortora (2002) suggests that clauses may contain an aspectual phrases field, where multiple aspectual phrases instantiate different components of aspect and that the locatives in the constructions under discussion can be placed in the aspectual phrases field of a clause. Tortora thus develops a hypothesis originally presented by Cinque (1999) about those Italian adverbs like già 'already' and più 'anymore' that contribute to the terminative aspectual interpretation and the perfective aspectual interpretation of the event. See also Poletto (2000) about the existence of an agreement field in the clause.

14 See Brandi/Cordin (1989).

15 See Cordin (1993). 
I give the cake to the kids

Accusative clitic doubling with pronouns

5 el m'ha ciamada mi

he me-clitic has called me

he called me

Negation doubling

6 No vegno miga con $t i$

I don't come miga (neg.) with you

I'm not coming with you

Interrogative modality doubling

7 Nen-te o sten-te?

Should we go-te (inter. clitic) or stay-te (inter.clitic)?

Should we go or stay?

\section{COMPARING ROMANCE AND GERMANIC VERB - LOCATIVE CON- STRUCTIONS}

The Trentino constructions quoted in $\$ 2$ present many analogies with German trennbare Verben, as it is illustrated in table 1, where a comparison is given between the two mentioned languages, Italian and English.

Table 1

Trentino

Standard Italian

German

English

nar via

uscire

molar zo

abbassare

tirarse su

raddrizzarsi

montar su

risalire

far su

fare, rifare

tiràrghe dré ( $\mathrm{a}$

assomigliare

qualchedun)

vènder fora

svendere

morìr fora

estinguere

scorlar zo

scuotere

giustar su

aggiustare

enviar via

avviare

taiar via

ritagliare

$\begin{array}{ll}\begin{array}{ll}\text { ausgehen } \\ \text { herunterlassen }\end{array} & \text { to go out } \\ \text { aufrichten } & \text { to let down } \\ \text { einsteigen } & \text { to go up } \\ \text { umbauen } & \text { to build, to put up } \\ \text { nach jemandem } & \text { to take after } \\ \text { schlagen } & \text { someone } \\ \text { ausverkaufen } & \text { to sell out } \\ \text { aussterben } & \text { to die (off) } \\ \text { abschütteln } & \text { to shake out } \\ \text { ausbessern } & \text { to fix } \\ \text { einleiten } & \text { to start (off) } \\ \text { abschneiden } & \text { to cut off }\end{array}$

The analogy between German trennbare Verben and the dialectal verb-locative constructions employed in northern Italy has been noticed by various authors, who have 
proposed that the Romance construction is the result of the influence of the German language on those Romance varieties which are more exposed to the linguistic contact. ${ }^{16}$ However, as we have already seen, the construction is not a quirk of northern Italian dialects, but the consequence of a tendency attested in the whole Romance area -although with different degrees of productivity- and this suggests that the Romance construction may be considered as an independent process. The hypothesis is also confirmed by ancient Romance languages, where this type of construction was widespread. ${ }^{17}$

Verb-locative combinations in Germanic and in Romance languages have also different morphological and syntactic properties: it has been noted that only Germanic languages permit nominal derivations from the construction, whereby Romance languages do not permit them. ${ }^{18}$ As for the syntactic properties, we know that in many Germanic languages (German, Norwegian, Danish, Icelandic) the inflected verb of a main clause moves from last into second position, leaving the locative alone. As a consequence, the two elements are usually separated by one or more phrases. By contrast, in Romance constructions the locative comes immediately after the verb. ${ }^{19}$ Romance locatives can only be separeted from the verb by clitic objects or "light" adverbs (temporal/aspectual: ancora 'still', mai 'never', sempre 'always', mica 'not at all'). ${ }^{20}$

16 See Plangg (1980) and Gsell (1982). A different account is presented by Kramer (1987).

${ }^{17}$ See Dufresne et alii (2003); Masini (2006); Jezek/Strik-Lievers (2010); Mateu/Rigau (2010); Cordin (2011).

18 For instance, in Italian la sottomissione dei ragazzi 'the subduing of the children' derives from the phrase sottomettere i ragazzi, 'to subdue the children'; however, from the phrase metter sotto $i$ ragazzi it is impossible to derive la missione (messa) sotto dei ragazzi. Similarily, in Northern Italian varieties we find: rider 'to laugh' from which risada 'laugh (the noun)' derives, and rider drio 'to deride' from which one cannot derive *risada drio 'derision'.

19 The adjacency of locatives to the verb could be accounted for considering them as elements belonging to a category intermediate between (+clitics) and (-clitics). In fact in the verb-locative constructions locatives, although tonic, share various properties with clitics: they cannot appear outside their clause (topicalized), they cannot be modified, and they cannot be coordinated with other elements. Following a proposal made in Cardinaletti (1995) and in Cardinaletti/Starke (1999) for some German and Italian pronouns and for some adverbs, we could call locatives combining with verbs "weak adverbs".

20 Consider the examples $\mathrm{v}$ and vi, respectively with a clitic and with a light adverb before the locative:

$\mathrm{v} \quad$ Non mandarlo fuori.

Do not send him out.

vi Tira sempre/ ancora /già fuori la lingua.

He sticks always /again / already out his tongue.

Neither direct and indirect objects (vii, viii), nor "heavy" adverbs (ix) can appear between the verb and the locative:

vii* Hai messo una moneta dentro. 
Finally, as a further confirmation of the independence of the Romance periphrases from German, I recall the Trentino examples given in the group h), $\$ 2$ that are formed with esser + dré/drio, 'to be after/behind ...', and have a progressive reading: they are not found in German varieties, therefore it is impossible to recognize them as calques.

Recently, from a different point of view, some scholars, comparing Germanic verb-locative constructions and Romance ones, have re-examined the typological distinction proposed by Talmy $(1991,2000)$ between verb framed languages and satellite languages..$^{21}$ According to Talmy's generalization, Romance languages should be considered verb framed, in that they express motion using verbs, whereas Germanic languages should be considered satellite languages, in that they express motion using a satellite around the verb, e.g. a particle. Iacobini and Masini (2007) argue against this generalization claiming that Italian - at the light of the data quoted in $\S 1$ - "does not conform to Talmy's generalization, since it behaves more like English than Spanish." Mateu/Rigau (2010: 242) reach a different conclusion, proposing that "Italian verbi sintagmatici resemble Germanic phrasal verbs, but only superficially". According to Mateu/Rigau, the crucial point is that in Romance non directional manner verbs cannot appear with a particle expressing path, while in Germanic languages pure manner verbs can co-appear with the locative particle, as illustrated by the contrast between the examples a-b in 8 and 9 :

8a. John danced the night off.

$\mathrm{b}^{*}$ *Gianni ha danzato fuori tutta la notte.

9a. John worked his debt off.

b *Gianni ha pagato fuori i suoi debiti.

In order to account for this difference, Mateu/Rigau (2010: 253) posit that Romance constructions obey a restriction, being allowed only where a concrete or abstract "path-feature" is spelled out by two different roots, both in the verb and in a directional particle. It follows therefore that "the list of verbs that enter into the Romance verb-particle constructions is reduced to those verbs encoding or involving

\footnotetext{
*You have put a coin inside.

viii* Darebbe a suo fratello contro.

${ }^{*} \mathrm{He}$ would give his brother against.

ix * Lo hai messo come niente fosse sotto.

* You have knocked him without noticing down.

${ }^{21}$ Among others, see Folli/Ramchand (2005); Horrocks/Stavrou (2007); Iacobini /Masini (2007); Spreafico (2009); Mateu Rigau (2010).
} 
directionality."22 Differently, Germanic particle constructions are also allowed with pure manner verbs.

This hypothesis, however, does not account immediately for those Trentino verblocative constructions quoted in $\S 2$ (groups $\mathrm{f}$, g), where locatives combine with verbs that do not encode directionality, or at least that do not encode only directionality. ${ }^{23}$

In order to explain all Romance cases, it seems in fact necessary to specify what the feature "directionality" involved in the verb means. We see that in many examples of northern Italian varieties the interpretation of directionality is not only rela-

22 Folli/Ramchand (2005) point out that in Italian only motion verbs involving a result feature can express the particle. They compare path verbs (correre 'to run', rotolare 'to roll', rimbalzare 'to bounce', scivolare 'to slide', gattonare 'to crawl', saltare 'to jump', volare 'to fly', saltellare 'to hop') that involve the direction feature and allow the verb-particle construction (correre fuori, rotolare giù, rimbalzare su, scivolare via, gattonare via, saltare su, giù, fuori, volare via, saltellare su) with manner of motion verbs (galleggiare 'to float', camminare 'to walk', galoppare 'to gallop', danzare 'to dance', nuotare 'to swim', sciare 'to ski', passeggiare 'to walk around', vagabondare 'to wander') that do not involve directionality and do not allow the construction. I note that Romance motion verbs that do not allow verb-particle constructions are unergative (in Italian they require the auxiliary avere 'to have'), in contrast with those motion verbs that allow the construction and are unaccusative (in Italian and in Trentino they require the auxiliary essere 'to be'). The contrast is clearly illustrated by the following couple of examples, $\mathrm{x}$ and $\mathrm{xi}$ :

$\mathrm{x}$ Gianni è corso su al parco.

John is run (has run) up to the park.

$\mathrm{xi}^{*}$ Gianni ha corso su al parco tutto il giorno.

John has run up to the park the whole day long.

We see that the same verb has a different behavior with the auxiliary avere 'to have'and with the auxiliary essere 'to be: in fact, only the unaccusative correre with the auxiliary essere allows a verb-locative construction.

23 One of the examples that Mateu/Rigau (2010: 243) quote for illustrating the contrast between the Germanic and the Romance construction is $8 \mathrm{a}$, that $\mathrm{I}$ repeat here:

$8 \mathrm{a}$ John danced the night off.

Like Italian, Trentino disallows this construction. Nonetheless, it is interesting to note that in this variety we can find a very similar construction (8c), where the adverb fora fora literally 'off off' appears, with an aspectual meaning corresponding to "in a continuous way, without interruption".

8c El Giani l'à balà fora e fora tuta la not.

John has gone on dancing all the night.

Fora fora in Trentino also appears in combination with other activity and motion verbs, as pianzer 'to cry', nodar 'to swim', ecc. (l'ha pianzest fora e fora per tut el viazo he went on crying during the whole journey', l'ha nodà fora e fora sin a la costa 'he went on swimming until he reached the coast'). The aspectual interpretation of the adverb fora fora is registered in Aneggi 1984, who translates the expression into the Italian di continuo, sempre 'continuously, always'. Analogously, another locative adverb with doubling drio a drio 'behind behind' is used in Trentino for expressing verbal aspect, as registered by Groff 1955, who translates it as 'di seguito, ininterrottamente' (consecutively, step by step). 
tive to space, but it is also relative to aspect: in fact it gives a sort of measure of the development of a process, expressing the endpoint (the success in reaching a complete result, or a partial result), or the start-point, or the intensity of the activity, or its progress. Only extending the interpretation of directionality in order to cover both space and time (phases of time), it is possible to give a coherent account for Romance verb-locative constructions, included the quoted Trentino examples, maintaining Talmy's distinction, according to Mateu/Rigau (2010).

\section{CONCLUDING REMARKS}

I summarize here the most relevant points discussed in paragraphs 1-3. First of all, I consider verb-locative construction a pan-Romance phenomenon. Even though the prefixal system typical of classical Latin has been codified in standard Romance languages, where it is still productive, non standard varieties attest a wide and varied employ of the verb-locative construction.

Apparently this construction is analogous to the Germanic verb-particle one, but a comparison between the two languages shows that the Romance one is the result of an independent process and is characterized by different morphological and syntactical properties: unlike Germanic, Romance languages do not allow nominal derivations from the construction; moreover, only in Romance constructions the locative must be adjacent to the verb (or come immediately after a clitic object, or after a "light" adverb) and cannot be separated from the verb by any constituent.

Further evidence comes from the diachronic analysis of Romance documents which confirm that the phenomenon in Romance area appears independently from the influence of Germanic languages, being attested since the beginning of vulgar languages and being not limited to calques.

Even though the linguistic contact between German and Romance varieties cannot be considered the cause of the diffusion of the construction in Romance area, it might have contributed to reinforce an autonomous tendency. In fact, the construction is more largely attested in the Rhaeto-Romance area and in the northern Italian regions that have German neighbours (Trentino, Friuli, the Ladin Dolomites), as well as in Veneto, in Lombardy and on the Appenines around Parma, which are regions that have had historical ties with Austria.

The comparison between different Romance varieties, and in particular between spoken Italian and northern Italian dialects, evidences a significant cross-linguistic variation in Romance area. The construction can be ranked along a continuous scale of directionality, whose poles are clearly defined: at one end we find the most transparent constructions with compositional meanings, which are formed by a verb of motion plus a locative expressing location or, more often, direction in space; at the other pole, we find those combinations that have non-compositional meanings, and are formed by a verb followed by a locative that has lost its spatial meaning, and has assumed a grammatical one, expressing an aspectual meaning. The intermediate verbs (group e, e') alternate between a concrete directional reading and a grammaticalized one. Only in some varieties, as in Trentino dialects (more in general in northern 
Italian varieties), the construction has reached the grammaticalization pole, where the locative functions as an explicit marker of a grammatical feature of the verb. ${ }^{24}$

Those varieties in which the construction has reached the most grammaticalized pole are characterized by the tendency of spelling out inflection elements, such as the agreement with the subject, with the dative object, etc. As a consequence, they frequently show doubling effects (subject doubling, case doubling, negation doubling).

Doubling leads to constructions containing an element which seems to be semantically superfluous. In verb-locative combinations, too, the locative often repeats a semantic feature inherent to the verb that seems redundant. Redundancy is often symptomatic of semantic erosion, and it is the first sign of a system's loss of productivity. The weakening of a number of systems (of subject agreement, ${ }^{25}$ morphological case, prefixes as expressions of aspect) may be the link between locative constructions and the doubling phenomena: it seems possible in fact that Trentino dialects make the functional features of a verb explicit in a new position in order to strengthen a weak system.

Further confirmation to the possible linking between doubling phenomena and verb-locative constructions in Romance comes from the recent discussion of the typological distinction between Germanic languages, in which the expression of events of motion is considered satellite-framed, and Romance languages, in which it is considered verb-framed. According to Mateu/Rigau (2010: 257), the verb-particle construction with path motion verbs in Romance languages can be accounted for by a structure in which the direction particle specifies the abstract path that has been copied into the verb: the same syntactic feature can be spelled out twice, both on the verbal root and on a "prepositional-like element".

Summarizing, Romance languages have maintained the possibility typical of Latin verb prefixes of expressing both space and aspect directionality in the verb. However, in their evolution some varieties that have been less codified have developed a new system of spelling out this feature, using a locative adverb after the verb in order to mark a direction/result feature, that is either the argument position of a motion verb or the verbal aspect of an event.

${ }^{24}$ I propose the following schema:

$\begin{array}{lll}\text { v-loc=spatial } & \text { v-loc-=end-point } & \text { v.loc=measure } \\ \text { direction } & \text { of the action } & \text { of the result } \\ + & - & - \\ + & + & - \\ + & + & +\end{array}$

25 Consider that in Trentino dialects verb endings for the III person singular are the same as those for the III person plural. 


\section{References}

ALTR - CORDIN, Patrizia (ed) (2005) L'Archivio lessicale dei dialetti trentini. Trento: Dipartimento di Scienze Filologiche e Storiche.

ANEGGI, Aldo (1984) Dizionario cembrano (triangolo Sover-Montesover-Piscine): parole e cose - frasi - modo di dire - proverbi del dialetto della valle di Cembra. S. Michele all'Adige (Trento): Museo degli usi e costumi della gente trentina.

BENINCÀ, Paola/POLETTO, Cecilia (2006) "Phrasal Verbs in Italian and Regional Italian.” In: F. Hinskens (ed) Language Variation. European Perspectives, Selected Papers from the third International Conference on Language Variation in Europe, Amsterdam, June 2005. Amsterdam: John Benjamin, 9-22.

BOOIJ, Geert/VAN KEMENADE, Ans (2003) "Preverbs: an introduction." In: G. Booij/J. van Marle (eds) Yearbook of Morphology. Dordrecht: Kluwer, 1-11.

BRANDI, Luciana/CORDIN, Patrizia (1989) "Two Italian Dialects and the Null Subject Parameter." In: O. Jaeggli/K. Safir (eds) The Null Subject Parameter. Dordrecht: Kluwer Academic, 111-142.

CALVO, Cesareo Rigual (2010) "I verbi sintagmatici italiani, con appunti contrastivi con lo spagnolo e il catalano." In: M. Iliescu/H. Siller Runggaldier/P. Danler (eds), vol. 7, 375-384.

CARDINALETTI, Anna/STARKE, Michael (1999) "The typology of structural deficiency: a case study of the three classes of pronouns." In: Riemsdijk H. van (ed) Clitics in the languages of Europe. Berlin, de Gruyter, 145-233.

CARDINALETTI, Anna/MUNARO, Nicola (eds) (2009) Italiano, italiani regionali e dialetti. Milano: FrancoAngeli.

CINI, Monica (ed) (2008) I verbi sintagmatici in italiano e nelle varietà dialettali. Stato dell'arte e prospettive di ricerca. Atti delle giornate di studi (Torino, 19-20 febbraio 2007). Frankfurt am Main: Peter Lang.

CINQUE, Guglielmo (1999) Adverbs and Functional Heads. A Cross-Linguistic Perspective. Oxford: Oxford University Press.

CORDIN, Patrizia (1993) "Dative Clitic Doubling in Trentino." In: A. Belletti (ed) Syntactic Theory and the Dialects of Italy. Torino: Rosenberg/Sellier, 130-154.

CORDIN, Patrizia (1997) "Tense, mood and aspect in the verb." In: M. Maiden/M. Parry (eds) The dialects of Italy. London: Routledge, 87-98.

CORDIN, Patrizia (2011) Le costruzioni verbo-locativo in area romanza. Dallo spazio all'aspetto. Berlin: de Gruyter.

DEHÉ, Nicole/JACKENDOFF, Ray/MCINTYRE, Andrew/URBAN, Silke (eds) (2002) Verb particle explorations, Berlin/New York: de Gruyter.

DUFRESNE, Monique/DUPUIS Fernande/TREMBLAY, Mireille (2003) "Preverbs and Particles in Old French." In: G. Booij/A. van Kemenade (eds), 33-60.

DURANTE, Marcello (1981) Dal latino all'italiano moderno. Saggio di storia linguistica e culturale. Bologna: Zanichelli.

FOLLI Raffaella/RAMCHAND Gillian (2005) "Prepositions and results in Italian and English: an Analysis from event decomposition." In: H. Verkuyl/H. de Swart/A. van Hout (eds) Perspectives on aspect. Dordrecht: Springer, 81-105. 
GRASSI, Corrado (2009) Dizionario del dialetto di Montagne di Trento. S. Michele all'Adige (Trento): Museo degli usi e costumi della gente trentina.

GROFF, Lorenzo (1955) Dizionario trentino-italiano. Trento: Monauni.

GSELL, Otto (1982) "Las rosas dattan ora - les röses da föra - le rose danno fuori: Verbalperiphrasen mit Ortsadverb im Rätoromanischen und im Italienischen." In: S. Heinz/U. Wandruszka (eds) Fakten und Theorien. Festschrift für Helmut Stimm. Tübingen: Narr, 71-85.

HORROCKS, Geoffrey/STAVROU, Melita (2007) "Grammaticalized aspect and spatio-temporal culmination." Lingua 117, 605-644.

IACOBINI , Claudio (2004) "Prefissazione." In: M. Grossmann/F. Rainer (edd), $L a$ formazione delle parole in italiano. Tübingen: Niemeyer, 98-163.

IACOBINI, Claudio/MASINI, Francesca (2007) "The emergence of verb-particle constructions in Italian: locative and actional meanings." Morphology 16, 155-188.

IACOBINI, Claudio/MASINI, Francesca (2009) "I verbi sintagmatici dell'italiano fra innovazione e persistenza: il ruolo dei dialetti." In: A. Cardinaletti/N. Munaro (eds), 115-135.

ILIESCU, Maria/SILLER RUNGGALDIER, Heidi/DANLER, Paul (eds) (2010) Actes du XXV Congrès international de linguistique et philologie romanes, Innsbruck, 3-8 septembre 2007, Voll. 7. Berlin: de Gruyter.

JANSEN, Hans (2004) "La particella spaziale e il suo combinarsi con verbi di movimento nell'italiano contemporaneo." In: P. D'Achille (ed) Generi, architetture e forme testuali. Firenze: Cesati, 129-144.

JEZEK, Elisabetta (2002) "Lo sfondamento di un confine tipologico. Il caso dei verbi complessi nell'italiano." In: P. Cordin/R. Franceschini/G. Held (eds) Parallela 8. Lingue di confine, confini di fenomeni linguistici. Grenzsprachen. Grenzen von linguistischen Phänomenen. Roma: Bulzoni, 289-306.

JEZEK, Elisabetta/STRIK-LIEVERS, Francesca (2010) "Verbi sintagmatici in italiano antico e moderno. Un'analisi corpus-based." In: M. Iliescu/H. Siller Runggaldier/P. Danler (eds), 445-454.

KING, Robert (2000) The Lexical Bases of Grammatical Borrowing. Amsterdam: Benjamins.

KRAMER, Johannes (1987) "Tedeschismi e pseudo tedeschismi nel ladino e altrove." Quaderni Patavini di Linguistica 6, 9-30.

MASINI, Francesca, (2006) "Diacronia dei verbi sintagmatici in italiano." Archivio Glottologico Italiano 91, 67-105.

MATEU, Jaume/RIGAU, Gemma (2010) "Verb-particle constructions in Romance. A lexical-syntactic account." Probus 22, 241-269.

PLANGG, Guntram (1980) "Le interferenze linguistiche: tedesco-ladino." Mondo ladino 3, 89-100.

POLETTO, Cecilia (2000) The higher functional field. Oxford: Oxford University Press.

POLETTO, Cecilia (2009) "I costrutti verbo + preposizione: l'interferenza tra veneto e italiano regionale.” In: A. Cardinaletti/N. Munaro (eds), 155-172. 
ROHLFS, Gerhard (1969) Grammatica storica della lingua italiana e dei suoi dialetti. Vol. 3, Sintassi e formazione delle parole. Torino: Einaudi.

SCHWARZE, Christoph (1985) "Uscire e andare fuori: struttura sintattica e semantica lessicale." In: A. Franchi De Bellis/L. Savoia (eds) Sintassi e morfologia della lingua italiana d'uso. Teorie e applicazioni descrittive. Atti del XVII Congresso internazionale di Studi della Società di Linguistica Italiana (Urbino 1983). Roma: Bulzoni, 355-371.

SIMONE, Raffaele (1997) "Esistono verbi sintagmatici in italiano?" In: T. De Mauro/V. Lo Cascio (eds) Lessico e grammatica. Roma: Bulzoni, 155-170.

SPIESS, Federico (1983) "L'unità lessicale composta di verbo e avverbio di luogo nei dialetti veneti." In: G. Holtus/M. Metzeltin (eds) Linguistica e dialettologia veneta. Studi offerti a Manlio Cortelazzo dai colleghi stranieri. Tübingen: Narr, $165-168$.

SPREAFICO, Lorenzo (2009) Problemi di tipologia lessicale. I verbi di moto nello Standard Average European. Roma: Bulzoni.

TALMY, Leonard (1991) "Path to Realization: a Typology of Event Conflation." In: Proceedings of the seventeenth annual meeting of the Berkeley Linguistics Society. Berkeley: Berkeley Linguistic Society, 480-519.

TALMY, Leonard (2000) Towards a cognitive semantics, Cambridge, MA, MIT Press. TORTORA, Cristina (2002) "Romance Enclisis, Prepositions and Aspect." Natural Language and Linguistic Theory 20, 725-756.

VICARIO, Federico (1997) I verbi analitici in friulano. Milano: FrancoAngeli.

VIGOLO, Maria Teresa (2007) "Indicatori spaziali in dialetti alto-veneti e in cadorino." In: R. Maschi/N. Penello/P. Rizzolatti (eds) Miscellanea di studi linguistici offerti a Laura Vanelli da amici e allievi padovani. Udine: Forum, 353-363.

VINCENT, Nigel (1999) "The evolution of c-structure: prepositions and PPs from Indo-European to Romance." Linguistics 37, 1111-1154.

Abstract

\section{FROM VERBAL PREFIXES TO DIRECTION/RESULT MARKERS IN ROMANCE}

In this paper I analyze verb-locative constructions in Romance. Even though not allowed in standard Romance languages, which have maintained and codified the classical Latin prefix system, these constructions are widely attested in non standard varieties, that are scarcely (or not at all) regularized. In this paper I deal in particular with a northern Italian variety, Trentino, where locatives, combining with some classes of verbs (unaccusative verbs and transitive activity verbs) can express not only concrete direction and metaphorical direction, but also aspect (the result of an activity or the progress of a process); in other words, they can express an abstract, more grammaticalized feature of direction. In fact, Trentino verb-locative constructions can express a specific phase of the development of an event, often the result (end-point) of an activity, or the start-point, or the progress, or the intensity of the activity itself. 
I argue that in Trentino (and in other similar dialectal varieties) locatives can function as grammatical markers both for arguments (in combination with motion verbs) and for aspect (in combination with verbs involving the feature of an abstract path). In a more general context, I note that locatives in combination of verbs function as goal/result markers in those varieties that tend to spell out markers of functional elements, frequently generating a repetition (doubling) of the same feature.

Finally, I compare Romance and Germanic constructions, noting that diachronic, grammatical and typological differences (with particular reference to Talmy's distinction between verb-framed languages and satellite languages) confirm the independence of Romance verblocative constructions.

\section{Povzetek \\ OD GLAGOLSKIH PREDPON DO OZNAČEVALCEV SMERI/REZULTATA V ROMANSKIH JEZIKIH}

V pričujočem članku analiziramo analitične konstrukcije glagola in prostega prostorskega morfema v romanskih jezikih. Čeprav te konstrukcije niso sprejemljive v knjižnih romanskih jezikih, ki so ohranili in normirali predponski sistem klasične latinščine, ostajajo široko rabljene $\mathrm{v}$ večinoma skoraj povsem nenormiranih neknjižnih zvrsteh. V članku se ukvarjamo zlasti s severnoitalijanskim trentinskim govorom, kjer lahko prosti prostorski morfemi v kombinacijami z nekaterimi vrstami glagolov (netožilniški glagoli in prehodni glagoli dejanja) izražajo ne samo konkretno oziroma metaforično smer, ampak tudi glagolski aspekt (rezultat dejanja oziroma trajajoči proces). Povedano drugače, izrazijo lahko abstraktne, bolj gramatikalizirane pomene smeri. V trentinskem govoru lahko omenjene analitične konstrukcije izražajo specifično fazo $\mathrm{v}$ razvoju dogodka, pogosto rezultat (zaključek) dejanja, njegov začetek ali razvoj, lahko tudi intenzivnost samega dejanja.

Zagovarjamo trditev, da $\mathrm{v}$ trentinskem govoru (in sorodnih dialektalnih različicah) prosti prostorski morfemi delujejo kot slovnični označevalci tako za argumente (ko se vežejo z glagoli premikanja) kot za glagolski aspekt (ko se vežejo z glagoli, ki vključujejo pomen abstraktne poti). Na splošno opažamo, da delujejo prosti prostorski morfemi v kombinaciji z glagoli kot označevalci cilja/rezultata $\mathrm{v}$ tistih govorih, ki težijo k uporabi označevalcev kot funkcionalnih elementov, ki vodijo pogosto $\mathrm{v}$ (redundantno) ponovitev iste pomenske poteze.

$\mathrm{V}$ zadnjem delu primerjamo konstrukcije $\mathrm{v}$ romanskih in germanskih jezikih, kjer lahko na podlagi diahronih, slovničnih in tipoloških razlik (tu se posebej opiramo na Talmyjevo razlikovanje med jeziki, osredinjenimi na glagol, in jeziki, ki se opirajo na glagolske satelite) potrdimo, da gre v primeru glagolskih konstrukcij s prostim prostorskim morfemom za neodvisno nastale romanske strukture. 